\title{
A RESPONSABILIDADE CIVIL DOS PAIS PELO ABANDONO AFETIVO DOS FILHOS MENORES
}

\author{
Fernando Roggia Gomes ${ }^{1}$
}

Resumo: Este artigo versa sobre a responsabilidade civil dos pais pelo abandono afetivo dos filhos menores. Nos dias atuais, o afeto constitui o principal elemento identificador da entidade familiar, fundamental à formação da criança e do adolescente. Sabe-se, porém, que comumente genitores deixam sua prole em situação de completo desamparo moral. Daí surge o questionamento sobre a possibilidade, ou não, de o filho abandonado ser indenizado por danos morais nessa hipótese. Tem-se como objetivo analisar tal questão por meio de entendimentos doutrinários e jurisprudenciais, bem como da legislação vigente e dos projetos de lei correlatos. Ao final, conclui-se que referido pleito é juridicamente possível, embora com alguns fatores condicionantes.

Palavras-chave: Família. Responsabilidade civil. Abandono afetivo. Filhos menores.

\section{INTRODUÇÃO}

presente artigo tem como objetivo geral analisar, por meio de entendimentos doutrinários e jurisprudenciais, bem como da legislação vigente e de projetos de lei, a (im)possibili-

1 Técnico Judiciário Auxiliar do Tribunal de Justiça de Santa Catarina. Formando em Direito pela Universidade do Sul de Santa Catarina - UNISUL. Email: fernandogomes@tjsc.jus.br. O presente artigo foi elaborado sob a orientação da professora Patrícia Fontanella. 
dade de responsabilização civil dos pais pelo abandono afetivo dos filhos menores.

Com a evolução do Direito de Família, especialmente após o advento da Carta Constitucional de 1988 e do Código Civil de 2002, o principal elemento identificador da entidade familiar passou a ser a afetividade.

Especificamente em relação aos filhos, sabe-se que o afeto dos genitores (aqui compreendido como convivência, atenção, educação, diálogo, entre outros fatores) é fundamental à formação psicológica, moral e emocional da criança e do adolescente, como seres em desenvolvimento que são. Todavia, é cediço que, em certas situações, por variados motivos, pais deixam de estabelecer qualquer relação com sua prole, colocando-a em situação de total desamparo afetivo. Daí emerge o questionamento sobre a possibilidade, ou não, de o filho ser indenizado por danos morais em tal circunstância.

A questão é complexa e deveras controvertida, motivo pelo qual reclama profunda reflexão e amplo debate pelo operador jurídico e, sobretudo, pela sociedade, de sorte a proporcionar, independentemente do entendimento que se adote, uma conscientização a respeito dos deveres dos genitores diante do hodierno conceito da família no ordenamento jurídico brasileiro.

\section{CONCEITO ATUAL DA FAMÍLIA NO BRASIL}

O conceito de família, conforme Gama $(2008$, p. 6), é relativo e se altera continuamente, de modo que qualquer análise não pode prescindir de enfocar o momento histórico e o sistema normativo em vigor.

Efetivamente, a evolução havida desde o Direito Romano "[...] é fruto de uma série de influências das mais variadas, cumprindo assinalar que as modificações ainda se encontram em andamento." (GAMA, 2008, p. 19).

No sistema jurídico brasileiro, como se sabe, durante muito tempo foi reconhecida apenas a legitimidade da família unida 
pelo casamento e os filhos originados dessa união (MADALENO, 2008, p. 5-6).

Essa visão patriarcal e exclusivamente matrimonializada, adotada no Brasil durante a colônia, império e boa parte do vigente período republicano, entrou em crise, o que resultou em sua derrocada no plano jurídico pelos valores introduzidos pela festejada Constituição de 1988 (LÔBO, 2008, p. 1).

Em verdade, o constituinte reconheceu as significativas modificações ocorridas no âmbito da família e, amoldando-se a uma nova realidade, promoveu uma série de alterações na ordem jurídica, as quais são sintetizadas por Lôbo $(2008$, p. 1) da seguinte forma: a) a proteção do Estado passou a alcançar qualquer entidade familiar, sem restrições; b) a família, entendida como entidade, assumiu claramente a posição de sujeito de direitos e obrigações; c) os interesses das pessoas humanas, integrantes da família, receberam primazia sobre os interesses patrimoniais; d) a natureza socioafetiva da filiação tornou-se gênero, abrangente das espécies biológica e não biológica; e) consumouse a igualdade entre gêneros e entre filhos; $f$ ) reafirmou-se a liberdade de constituir, manter e extinguir a entidade familiar e a liberdade de planejamento familiar, sem imposição estatal.

A sociedade brasileira se defrontou com um novo modelo de conjunto familiar, que possui como elemento caracterizador o afeto e é voltado para a realização individual de cada um de seus membros (MADALENO, 2008, p. 13).

Diniz (2009, p. 13) entende que se deve vislumbrar na família uma "[...] possibilidade de convivência, marcada pelo afeto e pelo amor, fundada não apenas no casamento, mas também no companheirismo, na adoção e na monoparentalidade".

Não é demais concluir, dessa forma, que a família contemporânea se fundamenta em valores e princípios totalmente diversos daqueles que outrora alicerçaram o modelo tradicional e oitocentista, que era matrimonial, hierarquizado e patrimonial (GAMA, 2008, p. 27). 
Assim, desde o final do século passado, alguns pensadores têm afirmado estar-se vivendo a era da pós-modernidade, a qual se caracteriza pelo rompimento com antigas verdades absolutas e é fruto de um razoavelmente lento evoluir de idéias, de concepções, de maneiras de se interpretar os fatos da vida e as relações humanas (HIRONAKA, 2008, p. 54-55).

A chamada pós-modernidade proporcionou um salto qualitativo ao Direito Civil no sentido de sua releitura e reposicionamento, de modo a estruturar-se uma nova dimensão que aproxima direito e ética (HIRONAKA, 2008, p. 57).

\section{PRINCIPIOLOGIA DO DIREITO DE FAMÍLIA}

A compreensão da família contemporânea necessariamente perpassa pelo exame dos princípios que a norteiam. Realiza-se, então, um brevíssimo estudo de alguns dos princípios regentes do Direito de Família que podem ser relacionados com o tema do presente artigo, a saber:

a) Princípio da dignidade da pessoa humana: instituído como fundamento da República Federativa do Brasil, encontra previsão no art. 1º III, da Constituição Cidadã (BRASIL, 1988). Para Bulos (2008, p. 392), o Texto Maior consagrou verdadeiro imperativo de justiça social, que possui conteúdo induvidosamente amplo, envolvendo valores espirituais (como liberdade de ser, pensar e criar) e materiais (como saúde, alimentação, lazer, entre outros). A dignidade da pessoa humana, enquanto vetor determinante da atividade interpretativa da Constituição, consigna um sobreprincípio, ombreando os demais pórticos constitucionais (BULOS, 2008, p. 393);

b) Princípio do melhor interesse da criança e do adolescente: em observância à doutrina da proteção integral, objetivase manter os menores a salvo de quaisquer efeitos nefastos à sua formação e desenvolvimento (PETRY JUNIOR, 2007, p. 111). Efetivamente, a maior vulnerabilidade e fragilidade dos 
infantes, como pessoas em desenvolvimento, justifica que sejam destinatários de um tratamento especial (DIAS, 2007, p. 65);

c) Princípio da paternidade responsável: em virtude desse princípio, há responsabilidade individual e social do homem e da mulher que, no exercício das liberdades inerentes à sexualidade e à procriação, geram uma nova vida humana, em favor da qual devem priorizar o bem-estar físico e psíquico, com todos os direitos fundamentais reconhecidos em seu favor (GAMA, 2008, p. 78);

d) Princípio da solidariedade familiar: decorrente do art. 3o, I, da CRFB/88, é resultado da imprescindibilidade da coexistência humana e da consciência racional dos interesses em comum, indicando o conjunto de instrumentos destinados a garantir uma existência digna, comum a todos, em uma sociedade livre e justa, sem excluídos ou marginalizados (MORAES, 2006, p. 46-48);

e) Princípio da convivência familiar: a importância da convivência familiar se justifica na medida em que é no seio da família que a pessoa nasce e se desenvolve, moldando sua personalidade ao mesmo tempo em que se integra ao meio social; é também na entidade familiar que geralmente se encontra amparo, conforto e refúgio (PEREIRA, 2004, p. 111);

f) Princípio da afetividade: Lôbo (2008, p. 47) define o princípio em questão como aquele "[...] que fundamenta o direito de família na estabilidade das relações socioafetivas e na comunhão de vida, com primazia sobre as considerações de caráter patrimonial ou biológico”.

Os princípios acima enumerados constituem a base dos fundamentos necessários para a compreensão da polêmica existente sobre a responsabilização civil dos pais pelo abandono afetivo dos filhos menores. Daí a relevância de seu estudo. Feito isso, trata-se, em seguida, da responsabilidade civil. 


\section{RESPONSABILIDADE CIVIL: TENTATIVA CONCEITUAL}

$O$ vocábulo responsabilidade tem sua origem no verbo latino respondere, significando a obrigação que alguém tem de assumir as conseqüências jurídicas de seus atos, contendo, ainda, a raiz latina spondeo, fórmula por meio da qual se vinculava, no Direito Romano, o devedor nos contratos verbais (DIAS, 2006, p. 15).

Antes de iniciar a tentativa conceitual, é de todo relevante frisar que a responsabilidade civil, no ordenamento jurídico brasileiro, encontra previsão constitucional no art. $5^{\circ}$, V e X, da Carta de Outubro (BRASIL, 1988).

O Código Civil (BRASIL, 2002), ademais, trata do tema em diversos dispositivos, dentre os quais se destacam os seguintes:

Art. 186. Aquele que, por ação ou omissão voluntária, negligência ou imprudência, violar direito e causar dano a outrem, ainda que exclusivamente moral, comete ato ilícito.

Art. 927. Aquele que, por ato ilícito (arts. 186 e 187), causar dano a outrem, fica obrigado a reparálo.

Grandes são as dificuldades que a doutrina tem enfrentado para conceituar a responsabilidade civil, ante a complexidade do tema.

Para Cavalieri Filho (2005, p. 24), “em apertada síntese, responsabilidade civil é um dever jurídico sucessivo que surge para recompor o dano decorrente da violação de um dever jurídico originário".

A noção jurídica de responsabilidade, conforme Gagliano e Pamplona Filho (2009, p. 9), "pressupõe a atividade danosa de alguém que, atuando a priori ilicitamente, viola uma norma jurídica preexistente (legal ou contratual), subordinando-se, dessa forma, às conseqüências de seu ato (obrigação de reparar)”.

Por fim, a conceituação de Diniz é formulada nos seguintes termos: 
A responsabilidade civil é a aplicação de medidas que obriguem uma pessoa a reparar dano moral ou patrimonial causado a terceiros, em razão de ato por ela mesma praticado, por pessoa por quem ela responde, por alguma coisa a ela pertencente ou de simples imposição legal. (DINIZ, 2009, p. 35).

Encerrado o estudo do conceito atual da família e da responsabilidade civil no ordenamento jurídico pátrio, cuidase, doravante, da questão que constitui o objeto deste artigo. Pergunta-se: é cabível responsabilizar civilmente os pais pelo abandono afetivo dos filhos menores?

O tema se reveste de grande importância na atualidade, especialmente diante dos contornos da família contemporânea, que, como visto, é predominantemente fundada em laços afetivos.

Antes de ingressar na discussão propriamente dita, contudo, reputa-se apropriado tecer considerações acerca da relevância dos genitores no sadio desenvolvimento dos filhos.

\section{A IMPORTÂNCIA DOS PAIS NA FORMAÇÃO DOS FILHOS}

Sabe-se que os pais são os principais responsáveis pela formação dos filhos e que a boa relação familiar entre a criança/ adolescente e seus genitores contribui sobremaneira para seu adequado desenvolvimento (ROLLIN, 2003, p. 39).

Durante a infância e a adolescência, o ser humano se encontra em uma fase peculiar de sua existência e as experiências vivenciadas ao longo dessa etapa da vida repercutem de forma significativa na formação de sua estrutura psíquica (LAURIA, 2002, p. 57-58).

Por meio da identificação dos genitores como modelos e da vivência afetiva com eles, bem como da oscilação entre amor e ódio com um e com outro, os seres humanos se tornam capazes de dirigir suas emoções, impulsos e sentimentos para fins socialmente aceitáveis (LAURIA, 2002, p. 72). 
É importante que o filho menor possa se relacionar com essas duas figuras (pai e mãe), porquanto a ausência, o desprezo ou a mera indiferença, seja da figura paterna, seja da figura materna, interferirão, no mais das vezes, de forma danosa em sua formação (ROLLIN, 2003, p. 39).

Cada genitor preenche uma gama específica de necessidades da prole. A mãe atua, sobretudo, nos cuidados mais primários, como o afeto aconchegante e o acompanhamento diário; já o pai, embora não dispensado de tais atribuições, desempenha importante papel quanto à segurança e firmeza da personalidade (RIZZARDO, 2008, p. 696).

É de conhecimento geral que, em algumas situações, pais negligenciam suas obrigações e acabam contribuindo de modo expressivo para que os filhos tomem caminhos ruinosos. Não é raro que os genitores deixem de estabelecer qualquer relação com sua prole, colocando-a em situação de total desamparo afetivo.

Pereira (2011) adverte que a ausência das funções dos pais se apresenta como um fenômeno social alarmante, que provavelmente tem gerado as péssimas conseqüências conhecidas por todos, como o aumento da delinqüência juvenil e o grande número de menores de rua.

Nessa diretriz, Velasquez salienta o seguinte:

$\mathrm{O}$ abandono e a negligência familiares e a falta de afeto e diálogo também são problemas comuns que afligem os jovens, não sendo de espantar que mais de $90 \%$ dos adolescentes infratores internados provenham de famílias bastante desestruturadas, marcadas por agressões físicas e emocionais, problemas psiquiátricos e pela ausência das figuras paterna e materna [...]. (VELASQUEZ, 2010).

Realmente, "seria ingenuidade pensar que esses sintomas sociais que o cotidiano nos escancara são conseqüência apenas do descaso do Estado e de uma economia perversa." (PEREIRA, 2011). 
Madaleno (2008, p. 318) pondera que os profissionais da Psicologia têm afirmado que o filho abandonado por seus pais sofre trauma e ansiedade, com nefasta repercussão em suas futuras relações, ressentidas de autoconfiança.

Por outro lado, se a criança cresce em um ambiente sadio, cercada de atenção pelos genitores, tende a desenvolver sua auto-estima, componente psicológico fundamental ao bom desempenho escolar, ao futuro sucesso profissional e ao bom relacionamento com as pessoas (NADER, 2009, p. 334).

Ressaltada a inestimável valia da real participação dos pais na vida dos filhos menores, procura-se demonstrar, a seguir, a proteção jurídica conferida ao afeto nas relações paterno-filiais.

\section{A PROTEÇÃO JURÍDICA DO AFETO NAS RELAÇÕES PATERNO-FILIAIS}

Inicialmente, é preciso esclarecer que inexiste no ordenamento jurídico brasileiro previsão legal expressa no sentido de impor aos pais o dever de prestar afeto aos filhos, de forma que, na realidade, tal dever decorre da análise conjunta de diversos dispositivos de lei e dos princípios que regem a família na atualidade.

A Constituição da República e a Lei n 8.069/90 acolheram a doutrina da proteção integral ao transformar a criança e o adolescente em sujeitos de direito, colocando-os a salvo de toda forma de negligência e lhes contemplando com um enorme número de garantias (DIAS, 2010, p. 452).

Assim, segundo o art. 227, caput, da Carta Magna, os direitos da criança e do adolescente (dentre os quais se inserem a dignidade, o respeito e a convivência familiar) devem ser assegurados pela família, sociedade e Estado com absoluta prioridade (BRASIL, 1988).

Oportuno transcrever o dispositivo, ante sua relevância:

Art. 227. É dever da família, da sociedade e do Estado assegurar à criança, ao adolescente e ao 
jovem, com absoluta prioridade, o direito à vida, à saúde, à alimentação, à educação, ao lazer, à profissionalização, à cultura, à dignidade, ao respeito, à liberdade e à convivência familiar e comunitária, além de colocá-los a salvo de toda forma de negligência, discriminação, exploração, violência, crueldade e opressão. (BRASIL, 1988).

Merece registro que a enumeração de direitos contida no texto constitucional - a qual, aliás, também é feita no art. 4ㅇ do ECA - não é exaustiva, cuidando-se de "norma aberta, com um mínimo legal, mas permissiva de uma interpretação ampla a permitir o respeito e aplicação da doutrina da proteção integral." (AMIN, 2010, p. 24).

Por sua vez, o Estatuto da Criança e do Adolescente dispõe que aos infantes devem ser disponibilizadas todas as condições para um satisfatório desenvolvimento mental, moral, espiritual e social, conforme se infere da leitura de seu art. 3o:

Art. 3० A criança e o adolescente gozam de todos os direitos fundamentais inerentes à pessoa humana, sem prejuízo da proteção integral de que trata esta Lei, assegurando-se-lhes, por lei ou por outros meios, todas as oportunidades e facilidades, a fim de lhes facultar o desenvolvimento físico, mental, moral, espiritual e social, em condições de liberdade e de dignidade. (BRASIL, 1990).

O art. 19 do citado diploma, ademais, garante-lhes o direito de serem criadas e educadas no seio de sua família, pois é nela que "[...] a criança e o adolescente vão se abrindo para o mundo e assimilando valores, hábitos e modos de superar as dificuldades, de formar o caráter e de introduzir-se na vida social." (CURY, 2003, p. 101).

A atenção e cuidado especiais a que fazem jus a criança e o adolescente devem ser iniciados no núcleo familiar, o qual se constitui em lugar central e de excelência para o desenvolvimento saudável da pessoa (RAMIDOFF, 2008, p. 316). 
Especificamente em relação aos deveres dos pais, o art. 229 do diploma constitucional preconiza que "os pais têm o dever de assistir, criar e educar os filhos menores [...]" (BRASIL, 1988).

Discorrendo sobre o dever de assistência próprio dos genitores, Maciel (2010, p. 119) assinala que:

Esta regra engloba, além do sustento, a assistência imaterial concernente ao afeto, ao cuidado e ao amor. [...]

Analisando a redação do art. 229 da CF/88, no que tange ao dever dos pais de assistir os filhos menores, notamos a amplitude do termo e as suas vertentes possíveis. Se, por um lado, significa ajudar, auxiliar e socorrer, por outro, há a vertente de estar presente, perto, comparecer, presenciar, acompanhar e até mesmo coabitar.

Sob esse ângulo, o vocábulo assistir adquire a conotação de participação dos pais, ativa e contínua, na vida dos filhos (MACIEL, 2010, p. 119).

Já de acordo com o art. 1.634, I e II, do Código Civil, compete aos pais, quanto à pessoa dos filhos menores, dirigirlhes a criação e educação, bem como tê-los em sua companhia e guarda (BRASIL, 2002).

A respeito do dispositivo acima mencionado, convém esclarecer que a noção de educação (inciso I) "[...] é abrangente e inclui tanto a educação escolar e profissional quanto a formação moral que se dá no ambiente familiar, contribuindo para a formação do indivíduo e do cidadão." (LEITE, 2005, p. 280). Nesse sentido, Diniz (2010, p. 1162) sustenta que os pais deverão dirigir a criação e educação dos filhos amoldando sua personalidade e dando-lhes boa formação moral. Coelho (2009, p. 189), ao abordar referido dever (criação e educação), relaciona-o com a idéia geral de preparação para a vida.

Quanto ao poder-dever de companhia e guarda, tem-se que este é necessário para que os pais possam dirigir a formação dos 
filhos, regendo seu comportamento e vigiando-os, até porque são civilmente responsáveis pelos atos lesivos por eles praticados (DINIZ, 2010, p. 1162).

Do cotejo dos dispositivos acima citados, depreende-se que não basta aos pais prover as necessidades materiais da prole (como alimentação, moradia, transporte e assistência médica); é igualmente essencial o suporte moral, que compreende a convivência diária, o diálogo, a educação, a participação, a transmissão de afeto, entre outros fatores (NADER, 2009, p. 344).

De fato, considerando que deve ser garantida à criança e ao adolescente a integral formação de sua personalidade, os genitores têm, por conseqüência, um compromisso natural de afeto em relação aos filhos menores (MADALENO, 2008, p. 321).

Para Dias (2010, p. 452), "o conceito atual da família, centrada do afeto como elemento agregador, exige dos pais o dever de criar e educar os filhos sem lhes omitir o carinho necessário para a formação plena de sua personalidade”, de forma que é cabível concluir que a assistência emocional também é uma obrigação legal dos genitores (MACIEL, 2010, p. 119).

\section{ABANDONO AFETIVO}

$\mathrm{Na}$ visão da Psicologia, "uma criança é um processo de construção de longo prazo que requer compromissos afetivos permanentes", de sorte que "a negligência afetiva é muito danosa" (IENCARELLI, 2009, p. 166-167). Realmente, "a deficiência e a privação de cuidado afetuoso obstruem a coesão e a estruturação saudável da mente de uma criança ao longo do seu desenvolvimento [...]" (IENCARELLI, 2009, p. 168).

É preciso esclarecer que o afeto sob o enfoque jurídico não deve ser interpretado como sendo apenas o sentimento de amor (GROENINGA, 2008, p. 79). A afetividade, para o Direito, não se confunde com o afeto como fato psicológico, de modo que "[...] a afetividade é dever imposto aos pais em relação aos 
filhos e destes em relação àqueles, ainda que haja desamor ou desafeição entre eles." (LÔBO, 2008, p. 48). O conceito abarca, assim, todo o suporte moral que os pais devem alcançar aos filhos, como a real participação em sua criação, a convivência, o diálogo, a educação, entre outros fatores.

Para Maciel (2010, p. 119), "a assistência imaterial traduz-se no apoio, no cuidado, na participação na vida do filho e no respeito por seus direitos da personalidade, como o direito de conviver no âmbito da família”.

Lôbo afirma que o abandono afetivo dos filhos nada mais é do que o inadimplemento dos deveres jurídicos da paternidade (LÔBO, 2008, p. 285). Já Hironaka, nesse passo, aclara:

O dano causado pelo abandono afetivo é antes de tudo um dano à personalidade do indivíduo. Macula o ser humano enquanto pessoa, dotada de personalidade, sendo certo que esta personalidade existe e se manifesta por meio do grupo familiar, responsável que é por incutir na criança o sentimento de responsabilidade social, por meio do cumprimento das prescrições, de forma a que ela possa, no futuro, assumir a sua plena capacidade de forma juridicamente aceita e socialmente aprovada. (HIRONAKA, 2011).

Para configurar ato ilícito, o abandono afetivo deve ser voluntário, pois se, por exemplo, o pai se afasta do filho em razão de ter contraído doença contagiosa, não há ilícito, visto que rompido o nexo de causalidade pela excludente da força maior. Cite-se, ainda, o caso de o guardião passar a residir em localidade distante e o não-guardião carecer de recursos financeiros para o encontro, hipótese na qual, em princípio, não estará caracterizado o abandono afetivo (NADER, 2009, p. 345).

Certo é, no entanto, que cada caso deve ser analisado em sua concretude, pois tais ocorrências, normalmente, não 
impedem o contato ao menos por telefone, cartas e e-mails (NADER, 2009, p. 345).

Também inexiste abandono quando o desencontro entre pai e filho decorre da ignorância da paternidade, pois se o pai biológico desconhece a existência do filho, não the pode ser imputado o descumprimento dos deveres paternos (NADER, 2009, p. 345).

\section{INTERPRETAÇÃO DOUTRINÁRIA}

A questão da (im)possibilidade de responsabilização civil dos genitores em caso de abandono afetivo dos filhos menores é relativamente nova e divide opiniões na doutrina, havendo uma gama de fundamentos a amparar cada um dos posicionamentos antagônicos existentes a esse respeito.

Inicia-se pelos autores favoráveis à tese, isto é, os que defendem ser o abandono afetivo fato apto a ensejar danos de ordem moral passíveis de reparação pecuniária.

Madaleno (2008, p. 319) assevera que, diferentemente dos adultos, os menores são incapazes de compreender a imotivada ausência do pai ou da mãe, fato que pode gerar o direito à reparação do agravo moral sofrido pela negativa do direito que tem a criança/adolescente à sadia convivência e referência parental.

$\mathrm{O}$ autor arremata nos seguintes termos:

Além do direito ao nome paterno, o filho tem a necessidade e o direito, e o pai tem o dever de acolher social e afetivamente o seu rebento, sendo esse acolhimento inerente ao desenvolvimento moral e psíquico de seu descendente. Recusando aos filhos esses caracteres indissociáveis de sua estrutura em formação, age o pai em injustificável ilicitude civil, e assim gera o dever de indenizar também a dor causada pelas carências, traumas e prejuízos morais sofridos pelo filho imotivadamente rejeitado pela desumana segregação do pai. (MADALENO, 2008, p. 319). 
No mesmo pensar, Lôbo (2008, p. 284) conclui que o princípio da paternidade responsável, estabelecido no art. 226 da Constituição, não se resume ao cumprimento do dever de assistência material, abrangendo também a assistência moral, dever jurídico cujo descumprimento pode levar à pretensão indenizatória.

Para Rizzardo, a convivência com os pais é direito que se impõe por reclamo da natureza humana e impedir esse impulso que emana do próprio ser traz graves frustrações na realização da afetividade, com irreparáveis efeitos que repercutirão negativamente vida afora, ensejando a indenização pelo dano moral que se abate sobre o filho (RIZZARDO, 2009, p. 698-699).

Na ótica de Dias (2010, p. 453), a omissão do genitor em exercer os encargos decorrentes do poder familiar, abstendo-se de cumprir o dever de ter o filho em sua companhia, produz danos emocionais merecedores de reparação. Segundo a autora, a simples penalização com a perda do poder familiar não basta e, isoladamente, pode constituir-se não em uma pena, mas bonificação pelo abandono.

Em reflexão sobre o tema, Pereira (2011) lança a seguinte indagação: a indenização não está "monetarizando" o afeto? A resposta, para o jurista, é que não se está, de forma alguma, quantificando o afeto, uma vez que o valor da indenização, nessa hipótese, possui função punitiva e, mais do que isso, educativa. Prossegue:

[...] não é possível obrigar ninguém a amar. No entanto, a esta desatenção e a este desafeto devem corresponder uma sanção, sob pena de termos um direito acéfalo, um direito vazio, um direito inexigível. Se um pai ou uma mãe não quiserem dar atenção, carinho e afeto àqueles que trouxeram ao mundo, ninguém pode obrigá-los, mas à sociedade cumpre o papel solidário de lhes dizer, de alguma forma, que isso não está certo e que tal atitude pode comprometer a formação e o caráter dessas pessoas abandonadas afetivamente. (PEREIRA, 2011). 
Nader (2009, p. 346) destaca que, embora haja direito à reparação moral na situação aqui tratada, a questão é bastante complexa e seriam raros na prática os casos de sucesso em tal pleito, porquanto o ônus da prova incumbiria ao ofendido e seria necessária a comprovação do dano psicológico, da conduta culposa do pai e/ou da mãe (responsabilidade subjetiva) e, por fim, do nexo de causalidade, todos de difícil apuração.

Para Gonçalves, os juízes devem ser extremamente cautelosos e "somente casos especiais, em que fique cabalmente demonstrada a influência negativa do descaso dos pais na formação e no desenvolvimento dos filhos, com rejeição pública e humilhante, justifica o pedido de indenização por danos morais." (GONÇALVES, 2010, p. 741).

Por outro lado, há autores que entendem não ser possivel a responsabilização civil no caso de abandono afetivo dos filhos menores, a exemplo de Carbone:

Na verdade, não existe dano moral nem situação similar que permita uma penalidade indenizatória por abandono afetivo. $\mathrm{O}$ pai deve cumprir suas responsabilidades financeiras. $\mathrm{O}$ pagamento regular da pensão alimentícia supre outras lacunas, inclusive sentimentais. Para sustentar o filho, os pais têm que trabalhar, com o objetivo de manter um bom nível de vida até a maioridade ou a formatura na faculdade. Isso já é um ato de afeto e respeito. (CARBONE, 2010).

Como se vê, de acordo com o autor, o simples apoio material aos filhos, como o ato do pagamento da pensão alimentícia, afigura-se suficiente e, além disso, representa afetividade.

Na relação entre pais e filhos, consoante Horne (2011), "a liberdade afetiva está acima de qualquer princípio componente da dignidade da pessoa humana, sob pena de gerar um dano ainda maior para ambos". Mais danoso do que a desvinculação afetiva, para o autor, é obrigar um pai a cumprir, por exemplo, 
o dever de visitar o filho sob o temor de uma futura ação de reparação de danos. Em seus dizeres, ademais:

Ao quantificar o afeto, outras situações poderiam ensejar a reparação civil. Haveria dano moral decorrente de maior ou menor grau de afeto. Um pai, que possui dois filhos e, entretanto, gosta mais de um do que do outro, poderia ser obrigado a ressarcir o filho prejudicado. Enfim, inúmeras situações surgiriam no dia a dia com base na quantificação do afeto. (HORNE, 2011).

$\mathrm{Na}$ mesma linha, Alheiros (2011) preconiza que o afeto não deve ser tido como um sentimento imposto ou a ser convencionado pelas pessoas, mas sim como algo que decorre naturalmente e não pode ser cobrado de ninguém. A autora admite que o afeto é fundamental para a constituição de uma família e, a partir disso, questiona: "como podem agora querer que a afetividade seja imposta a pais e filhos (ou quem sabe num futuro próximo queiram impô-la também a irmãos) fundandose apenas no vínculo sanguíneo que os ligam?". Destaca, ainda, que a convivência familiar constitucionalmente protegida deve decorrer de laços afetivos, e não somente de vínculo biológico, pois, "se assim não o fosse, a convivência familiar seria ineficaz ou até prejudicial para a criança, já que ela não seria uma relação de amor." (ALHEIROS, 2011).

Por isso, há quem entenda que a imposição de sanção pecuniária na situação aqui vertida pode gerar efeitos colaterais mais gravosos do que a desvinculação afetiva:

[...] podemos criar um problema mais grave. Muitos pais, não por amor, mas por temer a Justiça, passarão a exigir o direito de participar ativamente da vida do filho. Ainda que seja um mau pai, fará questão da convivência, e a mãe, zelosa, será obrigada a partilhar a guarda com alguém que claramente não possui qualquer afeto pela criança. A condição de amor compulsório poderá ser ainda pior que a ausência. (CASTRO, 2011). 
Para os defensores dessa linha de pensamento, a intervenção do Judiciário em questões relativas ao sentimento é perigosa em coloca em risco relações que não são de sua alçada (CASTRO, 2011).

Demonstrada a acirrada controvérsia doutrinária que circunda a responsabilização civil pelo abandono afetivo nas relações paterno-filiais, analisar-se-á, no próximo subitem, o tratamento jurisprudencial conferido à temática.

\section{INTERPRETAÇÃO JURISPRUDENCIAL}

Aos poucos, os Tribunais começam a se manifestar sobre o tema. Ainda não há um grande número de julgados, já que, além de se tratar de tese relativamente nova e bastante discutida, o lesado, por vezes, não leva seu pleito a juízo por motivos que passam por sentimentos de vergonha, medo e desilusão (LEVY, 2008, p. 63).

No ano de 2004, o extinto Tribunal de Alçada de Minas Gerais julgou, em sede de apelação cível, caso emblemático, decidindo ser indenizável a dor sofrida pelo abandono afetivo, em acórdão assim ementado:

INDENIZAC̣ÃO DANOS MORAIS - RELAC̣ÃO PATERNO-FILIAL - PRINCÍPIO DA DIGNIDADE DA PESSOA HUMANA - PRINCÍPIO DA AFETIVIDADE.

O dor sofrida pelo filho, em virtude do abandono paterno, que o privou do direito à convivência, ao amparo afetivo, moral e psíquico, deve ser indenizável, com fulcro no princípio da dignidade da pessoa humana. (MINAS GERAIS, 2004).

Tratou-se de caso em que o genitor, após se divorciar, continuou prestando alimentos ao filho menor (que permaneceu sob a guarda materna), mas deixou de manter com ele qualquer contato, abandonando-o afetivamente. 
O relator do recurso anotou em seu voto - acompanhado pelos demais julgadores - que a responsabilidade dos pais não se pauta unicamente no encargo alimentar, mas também no dever de possibilitar o desenvolvimento humano dos filhos, com base no princípio da dignidade da pessoa humana. Concluiu, então, estarem presentes o dano (ofensa à dignidade), a conduta ilícita (não cumprimento, pelo pai, do dever familiar de convívio e educação, por meio da afetividade) e, por fim, o nexo de causalidade. Assim, foi fixada indenização por danos morais no valor equivalente a 40 (quarenta) salários mínimos.

Contra referido decisum foi interposto recurso especial ao Superior Tribunal de Justiça. Ao debruçar-se sobre a questão, a Quarta Turma do Tribunal da Cidadania reformou o acórdão mineiro sob o entendimento de que o dano moral pressupõe ato ilícito e que o abandono afetivo é incapaz de gerar o direito à reparação pecuniária:

\section{RESPONSABILIDADE CIVIL. ABANDONO MORAL. REPARAÇÃO. DANOS MORAIS. IMPOSSIBILIDADE.}

1. A indenização por dano moral pressupõe a prática de ato ilícito, não rendendo ensejo à aplicabilidade da norma do art. 159 do Código Civil de 1916 o abandono afetivo, incapaz de reparação pecuniária.

2. Recurso especial conhecido e provido. (BRASIL, 2005).

Colhe-se do corpo do acórdão que, "como escapa ao arbítrio do Judiciário obrigar alguém a amar, ou a manter um relacionamento afetivo, nenhuma finalidade positiva seria alcançada com a indenização pleiteada" (BRASIL, 2005). De acordo com o entendimento do relator, já existe sanção prevista em lei para a hipótese de abandono moral: a perda do poder familiar. Ainda segundo o julgador, acolher a tese de responsabilização civil enterraria definitivamente a possibilidade de restabelecimento da relação paterno-filial entre os envolvidos. 
Convém ressaltar, entretanto, que a votação do julgado não foi unânime, tendo o Ministro Barros Monteiro divergido da maioria. Extrai-se do voto-vencido lavrado pelo Ministro:

Penso que daí decorre uma conduta ilícita da parte do genitor que, ao lado do dever de assistência material, tem o dever de dar assistência moral ao filho, de conviver com ele, de acompanhá-lo e de dar-lhe o necessário afeto. [...]

O dano resta evidenciado com o sofrimento, com a dor, com o abalo psíquico sofrido pelo autor durante todo esse tempo. [...]

Penso também, que a destituição do poder familiar, que é uma sanção do Direito de Família, não interfere na indenização por dano moral, ou seja, a indenização é devida além dessa outra sanção [...]. (BRASIL, 2005).

Como se vê, o Ministro vencido sustentou que, além do dever de assistência material, o genitor tem o dever de alcançar assistência moral ao filho menor, além do que a destituição do poder familiar não obsta a indenização por danos morais.

Em seguida, contra a decisão em apreço foi interposto recurso extraordinário para o Supremo Tribunal Federal, o qual, porém, não foi conhecido sob o fundamento de que a análise da indenização por danos morais reside no âmbito da legislação infraconstitucional (BRASIL, 2009).

Outra ação paradigmática promovida pelos mesmos fundamentos (danos morais em decorrência do abandono afetivo) tramitou na Comarca de Capão da Canoa/RS, tendo os pedidos sido julgados procedentes, com a condenação do genitor ao pagamento de danos morais à filha. Ante a ausência de interposição de recurso, a sentença transitou em julgado.

No decisum, o julgador frisou que a educação não abrange somente a escolaridade, "[...] mas também a convivência familiar, o afeto, amor, carinho, ir ao parque, jogar futebol, brincar, passear, visitar, estabelecer paradigmas, criar condições para que 
a criança se autoafirme". Anotou, ainda, que "é menos aviltante, com certeza, ao ser humano dizer 'fui indevidamente incluído no SPC' a dizer 'fui indevidamente rejeitado por meu pai'”.

Os casos acima descritos, que ganharam ampla divulgação nacional no meio jurídico, indicam a controvérsia que permeia a matéria. Os demais Tribunais pátrios, da mesma forma, têm demonstrado que a questão está longe de ser pacificada.

O Tribunal de Justiça de Santa Catarina já se pronunciou no sentido de que "[...] o filho não pode obrigar o pai a nutrir amor e carinho por ele, e por este mesmo motivo, não há fundamento para reparação pecuniária por abandono afetivo." (SANTA CATARINA, 2010). Na fundamentação do acórdão em tela, registrou-se que a tristeza e a angústia sentidas pelo filho em razão de ter sido rejeitado pelo pai não constituem causa apta a caracterizar danos morais.

A mesma Corte de Justiça, contudo, já havia anteriormente decidido em sentido diametralmente oposto, assentando que "o pai que se omite em cuidar do filho, abandonando-o, ofende a integridade psicossomática deste, acarretando ilícito ensejador de reparação moral.” (SANTA CATARINA, 2008). Consignou-se no corpo do julgado que, diante dos efeitos negativos da ausência do genitor na vida do filho, o abandono afetivo constitui ato atentatório à dignidade da pessoa humana hábil a gerar dano de ordem moral.

Assim, pela análise dos precedentes jurisprudenciais supra, nota-se que a (im)possibilidade de reparação moral por conta do abandono afetivo é tópico cujo entendimento ainda não foi sedimentado pelos Tribunais pátrios.

\section{PROJETOS DE LEI SOBRE O TEMA}

Por fim, urge destacar que a temática do abandono moral, além se fazer presente nos embates doutrinários e jurisprudenciais, igualmente aportou no Poder Legislativo, uma vez que, 
atualmente, há dois projetos de lei em tramitação no Congresso Nacional a esse respeito.

O Projeto de Lei do Senado $n^{\circ} 700 / 2007$, de autoria do Senador Marcelo Crivella, propõe a modificação do Estatuto da Criança e do Adolescente, alterando diversos de seus dispositivos, para caracterizar o abandono moral como ilícito civil e penal. Exemplificativamente, ao art. 5 do ECA seria acrescido parágrafo único com a seguinte redação:

Parágrafo único. Considera-se conduta ilícita, sujeita a reparação de danos, sem prejuízo de outras sanções cabíveis, a ação ou a omissão que ofenda direito fundamental de criança ou adolescente previsto nesta Lei, incluindo os casos de abandono moral. (SENADO FEDERAL, 2011).

Entre os fundamentos constantes na justificativa do projeto está o de que os cuidados devidos às crianças e aos adolescentes compreendem atenção, presença e orientação por parte dos pais, além do que se faz necessário superar o atual estágio de insegurança jurídica caracterizado pelas decisões divergentes sobre o assunto (SENADO FEDERAL, 2011).

Já o Projeto de Lei n 4294/2008, do Deputado Carlos Bezerra, prevê, entre outras disposições, a inserção de parágrafo único no art. 1.632 do Código Civil, com a seguinte redação: "O abandono afetivo sujeita os pais ao pagamento de indenização por dano moral." (CÂMARA DOS DEPUTADOS, 2011).

Extrai-se da justificação do citado projeto que, na relação paterno-filial, existe a necessidade de auxílio moral, consistente na prestação de apoio, afeto e atenção, fatores indispensáveis ao adequado desenvolvimento da personalidade dos filhos. Para o autor, se é certo que não é possível obrigar pais e filhos a se amar, é preciso, ao menos, permitir ao prejudicado o recebimento de indenização pelo dano causado (CÂMARA DOS DEPUTADOS, 2011). 


\section{CONCLUSÃo}

Em decorrência do processo evolutivo sofrido pelo Direito de Família, sobretudo após a promulgação da Magna Carta de 1988 e do Código Civil de 2002, o afeto passou a ser o principal elemento caracterizador da entidade familiar.

Assim, ante a nova roupagem conferida à família contemporânea, que se afirma como local de realização pessoal de cada um de seus membros, surgiu, entre outros, o debate sobre a (im) possibilidade da responsabilização civil dos pais pelo abandono afetivo dos filhos menores, cuja solução tem se demonstrado bastante controvertida na doutrina e na jurisprudência.

Os adeptos da corrente que preconiza ser possível tal responsabilização sustentam, em resumo: a) os pais não têm apenas o dever de assistência material, mas também o dever de assistência moral em relação aos filhos; b) a ausência desse apoio viola os princípios norteadores do Direito de Família; c) a simples penalização com a perda do poder familiar não é suficiente e, ademais, constitui instituto do Direito de Família que não deve interferir na responsabilização civil; d) o dever de educação, previsto no art. 1.634, I, do Código Civil, pressupõe a efetiva participação dos pais na vida dos filhos; e) não se está quantificando o afeto, pois a indenização por danos morais exerce também, e principalmente, seu caráter pedagógico.

Por seu turno, a vertente contrária entende ser descabida a condenação por danos morais em tal circunstância, sob os seguintes fundamentos: a) a lei somente impõe aos pais o dever de assistência material à prole; b) o afeto deve decorrer naturalmente, e não ser imposto ou convencionado pelas pessoas; c) obrigar a convivência familiar seria ineficaz e possivelmente prejudicial à criança e ao adolescente; d) já existe sanção prevista em lei para a hipótese de abandono moral: a perda do poder familiar; e) não compete ao Judiciário obrigar alguém a amar; f) o abandono afetivo, embora censurável moralmente, não constitui, no campo jurídico, ato ilícito hábil a gerar responsabilização civil. 
Após acurado exame do regramento e da principiologia que regem a matéria, bem como sopesados os posicionamentos doutrinários e jurisprudenciais existentes, entende-se ser juridicamente possível a responsabilização civil dos pais pelo abandono afetivo dos filhos menores.

De fato, tendo em vista que os direitos das crianças e adolescentes devem ser tratados com absoluta prioridade (art. 227 da Lei Maior) e que a elas devem ser disponibilizadas todas as condições para um satisfatório desenvolvimento mental e moral (art. 30 do Estatuto da Criança e do Adolescente), bem como que o afeto é indispensável à sua formação, evidencia-se que, entre os deveres dos pais, insere-se o de proporcionar apoio moral aos filhos.

A propósito, a Constituição da República (art. 229) e o Código Civil (art. 1634) impõem aos genitores o dever de assistir, criar e educar os filhos, além do que o Estatuto da Criança e do Adolescente (art. 19) assegura o direito à convivência familiar, de modo que se afigura inaceitável crer que os deveres dos pais se esgotem com obrigações de ordem meramente material.

A principiologia correlata, sem dúvida, converge para a mesma conclusão. É evidente que o abandono afetivo implica afronta aos princípios da dignidade da pessoa humana, afetividade, melhor interesse da criança e do adolescente, paternidade responsável, solidariedade e convivência familiar.

Além disso, a destituição do poder familiar não pode constituir obstáculo para a reparação civil, uma vez que, além de inexistir fundamento legal para tal conclusão, a simples penalização com aquele instituto do Direito de Família seria ineficaz e, ainda, poderia vir em favor do genitor que abandona, o qual, por óbvio, não possui interesse em se relacionar com a prole.

Importa registrar que, embora não haja previsão legal expressa no sentido de que o abandono afetivo seja passível de reparação civil, também inexiste qualquer proibição em lei a esse respeito, de forma que tal ato pode ser considerado ilícito 
(art. 186 do Código Civil), pois representa flagrante violação aos direitos da criança ou adolescente, com danos em sua personalidade. Por conseguinte, deve incidir a regra geral no sentido de que o causador do dano fica obrigado a repará-lo (art. 927 do Código Civil).

Não se está afirmando, porém, que a simples ausência de convívio entre pai/mãe e filho, por si só, enseja a responsabilização civil. Na realidade, ainda que se entenda juridicamente possível o pleito, deverão estar devidamente preenchidos e comprovados todos os pressupostos da responsabilidade civil: a) ação ou omissão (conduta voluntária do genitor para abandonar o filho); b) dano (lesão de ordem moral sofrida pelo menor abandonado); c) nexo de causalidade (vínculo entre a conduta e o dano); d) culpa (dolo ou negligência por parte do autor do ato).

Não é demais lembrar que o ônus de tal prova, em princípio, recairá sobre o autor da demanda (filho abandonado), a teor do disposto no art. 333, I, do Código de Processo Civil.

Logo, a ação de indenização por danos morais em decorrência de abandono afetivo não deve ser encarada como um meio de simples vingança ou de lucro fácil. O Judiciário deverá estar atento à casuística, afastando eventuais pedidos desarrazoados.

O objetivo, a bem da verdade, é reparar os danos causados pela conduta voluntária de genitores negligentes. Ganha especial relevo, aliás, a função pedagógica da responsabilidade civil, isto é, punir para que não se reitere, advertindo os demais a não cometer ato ilícito análogo.

O fato é que a responsabilização civil dos pais pelo abandono afetivo dos filhos menores, se utilizada adequadamente e sem abusos, evitando-se a vulgarização do instituto, poderá servir como instrumento de altíssima relevância para a concretização dos direitos da criança e do adolescente, bem como para a conscientização da sociedade quanto aos deveres impostos aos genitores. 


\begin{abstract}
This article approaches the civil responsibility of parents for affective abandonment of minor children. Nowadays, the affection constitutes the main identifier element of the family, essential for the formation of children and adolescents. It's known, however, that parents sometimes leave their children in a situation of moral abandonment. So it arises the question about the possibility, or not, of the abandoned son being compensated for moral damages in this case. The objective is to analyze this question through doctrinal and jurisprudential understandings, in addition to the legislation and projects of law concerning to it. In the end, the conclusion is the request is juridically possible, but with some conditioning factors.
\end{abstract}

Keywords: Family. Civil responsibility. Affective abandonment. Minor children.

\title{
REFERÊNCIAS
}

ALHEIROS, Danielle. A impossibilidade de responsabilização civil dos pais por abandono afetivo. Disponível em: <http://jus.uol.com.br/revista/ texto/12987/a-impossibilidade-de-responsabilizacao-civil-dos-pais-porabandono-afetivo>. Acesso em: 05 maio 2011.

BRASIL. Constituição da República Federativa do Brasil de 1988. Disponível em:

<http://www.planalto.gov.br/ccivil_03/constituicao/constitui\%C3\%A7ao. htm>. Acesso em: 24 out. 2010.

BRASIL. Lei no 10.406, de 10 de janeiro de 2002. Institui o Código Civil. Disponível em: <http://www.planalto.gov.br/CCIVIL/leis/2002/L10406. htm>. Acesso em: 24 out. 2010.

BRASIL. Lei no 8.069, de 13 de julho de 1990. Dispõe sobre o Estatuto da Criança e do Adolescente e dá outras providências. Disponível em: <http:// www.planalto.gov.br/ccivil_03/Leis/L8069.htm>. Acesso em: 07 dez. 2010.

BRASIL. Superior Tribunal de Justiça. Recurso Especial no 757.411/MG. Relator: Min. Fernando Gonçalves, DF, 29/11/2005. Disponível em: 
<http://www.stj.jus.br/SCON/jurisprudencia/toc.jsp?tipo_visualizacao= null\&livre $=\% 22$ abandono + afetivo $\% 22 \&$ processo $=757411 \& b=A C O R>$. Acesso em: 25 out. 2010.

BRASIL. Supremo Tribunal Federal. Recurso Extraordinário n 567.164-0/ MG. Relatora: Min. Ellen Gracie, DF, 14/05/2009. Disponível em: <http://www.stf.jus.br/portal/diarioJustica/verDiarioProcesso.asp?numDj= $101 \&$ dataPublicacaoDj $=02 / 06 / 2009 \&$ incidente $=2567008 \&$ codCapitulo $=$ 6\& numMateria $=80 \&$ codMateria=3>. Acesso em: 22 abr. 2011.

BULOS, Uadi Lammêgo. Curso de direito constitucional. 2. ed. São Paulo: Saraiva, 2008.

CÂMARA DOS DEPUTADOS. Projeto de Lei $n^{\circ}$ 4294/2008. Acrescenta parágrafo ao artigo 1.632 do Código Civil e ao art. $3^{\circ}$ do Estatuto do Idoso, de modo a estabelecer a indenização por dano moral em razão do abandono afetivo. Disponível em: <http://www.camara.gov.br/sileg/ integras/613432.pdf>. Acesso em: 11 maio 2011.

CARBONE, Angelo. Abandono afetivo e a justiça. Disponivel em: <http:// www.parana-online.com.br/canal/direito-e justica/news/155565/?noticia= ABANDONO+AFETIVO+E+A+JUSTICA>. Acesso em: 25 out. 2010.

CASTRO, Leonardo. O preço do abandono afetivo. Disponível em: <http:// www.webartigos.com/articles/2866/1/O-Preco-Do-Abandono-Afetivo/ pagina1.html>. Acesso em: 09 maio 2011.

CAVALIERI FILHO, Sergio. Programa de responsabilidade civil. 6. ed. São Paulo: Malheiros, 2005.

COELHO, Fábio Ulhoa. Curso de direito civil: família; sucessões. 2. ed. São Paulo: Saraiva, 2009. v. 5.

DIAS, José de Aguiar. Da responsabilidade civil. 11. ed. Rio de Janeiro: Renovar, 2006.

DIAS, Maria Berenice. Manual de direito das famílias. 4. ed. São Paulo: Revista dos Tribunais, 2007.

Tribunais, 2010.

. Manual de direito das famílias. 6. ed. São Paulo: Revista dos

DINIZ, Maria Helena. Código Civil anotado. 15. ed. São Paulo: Saraiva, 2010. 
. Curso de direito civil brasileiro: direito de família. 24. ed. São Paulo: Saraiva, 2009. v. 5.

GAGLIANO, Pablo Stolze; PAMPLONA FILHO, Rodolfo. Novo curso de direito civil: responsabilidade civil. 7. ed. São Paulo: Saraiva, 2009.

GAMA, Guilherme Calmon Nogueira da. Princípios constitucionais de direito de familia. São Paulo: Atlas, 2008.

GONÇALVES, Carlos Roberto. Responsabilidade civil. 12. ed. São Paulo: Saraiva, 2010.

HIRONAKA, Giselda Maria Fernandes Novaes. A incessante travessia dos tempos e a renovação dos paradigmas: a família, seu status e seu enquadramento na pós-modernidade. In: BASTOS, Eliana Ferreira; DIAS, Maria Berenice (Coord.). A família além dos mitos. Belo Horizonte: Del Rey, 2008. p. 49-80.

. Pressupostos, elementos e limites do dever de indenizar por abandono afetivo. Disponivel em: <http://www.buscalegis.ufsc.br/revistas/ index.php/buscalegis/article/viewFile/9365/8931>. Acesso em: 05 maio 2011.

HORNE, Francisco Alejandro. O não cabimento de danos morais por abandono afetivo do pai. Disponível em: <http://www.ibdfam.org. $\mathrm{br} /$ ?artigos\& artigo=298>. Acesso em: 05 maio 2011.

IENCARELLI, Ana Maria. Quem cuida ama - sobre a importância do cuidado e do afeto no desenvolvimento e na saúde da criança. In: PEREIRA, Tânia da Silva; OLIVEIRA, Guilherme de (Coords.). Cuidado e vulnerabilidade. São Paulo: Atlas, 2009. p. 163-169.

LEVY, Fernanda Rocha Lourenço. Guarda de filhos: os conflitos no exercício do poder familiar. São Paulo: Atlas, 2008.

LÔBO, Paulo. Direito civil: famílias. São Paulo: Saraiva, 2008.

MACIEL, Kátia Regina Ferreira Lobo Andrade. Poder familiar. In: MACIEL, Kátia Regina Ferreira Lobo Andrade (Coord.). Curso de direito da criança e do adolescente: aspectos teóricos e práticos. Rio de Janeiro: Lúmen Júris, 2010. p. 81-149.

MADALENO, Rolf. Curso de direito de família. Rio de Janeiro: Forense, 2008. 
MINAS GERAIS. Tribunal de Justiça. Apelação Cível n 408.550-5. Relator: Des. Unias Silva. Belo Horizonte. 01 abr. 2004. Disponível em: $<$ http://www.tjmg.jus.br/juridico/jt_/inteiro_teor.jsp?tipoTribunal=2\&co mrCodigo $=0 \&$ ano $=0 \&$ txt $\_$processo $=408550 \&$ complemento $=0 \&$ sequenci $\mathrm{al}=0$ \& palavrasConsulta $=$ "que o privou do direito à convivência, ao amparo afetivo $" \&$ todas $=\&$ expressao $=\&$ qualquer $=\&$ sem $=\&$ radical $=>$. Acesso em: 24 out. 2010.

MORAES, Maria Celina Bodin de. O princípio da dignidade humana. In: MORAES, Maria Celina Bodin de (coord.). Princípios do direito civil contemporâneo. Rio de Janeiro: Renovar, 2006. p. 1-60.

NADER, Paulo. Curso de direito civil: responsabilidade civil. 2. ed. Rio de Janeiro: Forense, 2009.

PEREIRA, Rodrigo da Cunha. As conseqüências da ausência do pai.

Disponível em: <http://www.rodrigodacunha.info/reportagem04.html>. Acesso em: 18 abr. 2011.

. Nem só de pão vive o homem: responsabilidade civil por abandono afetivo. Disponivel em:<http://www.ibdfam.org.br/?artigos\&artigo=392>. Acesso em: 05 maio 2011.

. Principios fundamentais e norteadores para a organização jurídica da família. 2004. 157 f. Tese (Doutorado)-Universidade Federal do Paraná, Curitiba, 2004. Disponível em: <http://dspace.c3sl.ufpr.br:8080/d space/bitstream/1884/2272/1/Tese_Dr.\%20Rodrigo\%20da\%20Cunha. pdf>. Acesso em: 21 abr. 2011.

PETRY JUNIOR, Henry. Separação com causa culposa: uma leitura à luz da hermenêutica constitucional. Florianópolis: Conceito Editorial, 2007.

RAMIDOFF, Mário Luiz. Direito da criança e do adolescente: teoria jurídica da proteção integral. Curitiba: Vicentina, 2008.

RIZZARDO, Arnaldo. Responsabilidade civil: Lei no 10.406, de 10.01.2002. 4. ed. Rio de Janeiro: Forense, 2009.

ROLLIN, Cristiane Flôres Soares. Paternidade responsável em direção ao melhor interesse da criança. In: PORTO, Sérgio Gilberto; USTÁRROZ, Daniel (org.). Tendências constitucionais no direito de família. Porto Alegre: Livraria do Advogado, 2003. p. 35-49. 
SANTA CATARINA. Tribunal de Justiça. Apelação Cível $n^{\circ}$ 2006.015053-0. Relator: Monteiro Rocha. Florianópolis, 10 de dezembro de 2008. Disponível em: <http://tjsc6.tj.sc.gov.br/cposg/ pcpoQuestConvPDFframeset.jsp? cdProcesso $=0100087$ YH0000\& nuSeqPro cessoMv $=54 \&$ tipoDocumento=D\& nuDocumento=1296398>. Acesso em: 22 abr. 2011.

SANTA CATARINA. Tribunal de Justiça. Apelação Cível nº 2010.029238-1. Relator: Marcus Tulio Sartorato. Florianópolis, 15 de junho de 2010. Disponível em: <http://tjsc6.tj.sc.gov.br/cposg/ pcpoQuestConvPDFframeset.jsp?cdProcesso $=01000$ GAI10000\& nuSeqPro cessoMv=29\& tipoDocumento=D\&nuDocumento=2520672>. Acesso em: 22 abr. 2011.

SENADO FEDERAL. Projeto de Lei do Senado $n^{\circ} 700 / 2007$. Modifica a Lei $n^{\circ} .8 .069$, de 13 de julho de 1990, para caracterizar o abandono moral como ilícito civil e penal, e dá outras providências. Disponível em: <http:// legis.senado.gov.br/mate-pdf/11978.pdf>. Acesso em: 11 maio 2011.

VELASQUEZ, Miguel Granato. HECATOMBE X ECA. Disponível em: <http://www.mp.rs.gov.br/infancia/doutrina/id527.htm>. Acesso em: 17 out. 2010 